\title{
A new species of oral Streptococcus isolated from Sprague-Dawley rats, Streptococcus orisratti sp. nov.
}

\author{
H. Zhu, ${ }^{1,2}$ M. D. P. Willcox ${ }^{2}$ and K. W. Knox ${ }^{1}$
}

Author for correspondence: H. Zhu (CRCERT). Tel: +6129385 0273. Fax: +61293850202. e-mail: hzhu@cclru.randwick.unsw.edu.au

1 Institute of Dental Research, 2 Chalmers Street, Surry Hills, NSW 2010, Australia

2 Cooperative Research Centre for Eye Research and Technology (CRCERT), University of New South Wales, Sydney, NSW 2052, Australia

\begin{abstract}
Taxonomic studies were performed on an unusual oral Streptococcus strain isolated from Sprague-Dawley rats. The isolates were $\alpha$-haemolytic, biletolerant, aesculin-hydrolytic and unable to grow in $6.5 \% \mathrm{NaCl}$. They fermented lactose, sucrose and trehalose. They were distinguished from other recognized species of oral and viridans streptococci by several biochemical characteristics and by Lancefield's group antigen, as well as by unique DNA-DNA hybridization characteristics. 16S rDNA sequence studies confirmed the genealogical distinctiveness of the species. The results of the study demonstrated that the isolates represented a new species of the oral and viridans streptococci. The name Streptococcus orisratti sp. nov. is proposed for the new species. The type strain is A63 $^{\top}$ ( $=$ ATCC 700640 $^{\top}$ ).
\end{abstract}

Keywords: Viridans streptococci, taxonomy, DNA-DNA hybridization, rDNA sequencing, rat

\section{INTRODUCTION}

Viridans streptococci comprise a large proportion of the normal human oral bacteria and have been associated with dental caries, endocarditis, septicaemia and abscess formation. However, in comparison with $\beta$-haemolytic streptococci, the viridans streptococci have relatively low virulence and give poor or variable reactions in serological and conventional physiological tests. Despite the considerable efforts of microbiologists to classify the viridans streptococci (Colman, 1976; Drucker \& Melville, 1971; Facklam, 1977; Gilmour et al., 1987; Hardie \& Bowden, 1976; Parker \& Ball, 1976), there is no universally accepted system and consequently, in most studies, some strains remain unclassified.

The oral viridans streptococci of humans have been studied extensively. The most prevalent streptococci isolated from the human oral cavity are members of the Streptococcus sanguinis group, including $S$. sanguinis, Streptococcus gordonii, Streptococcus mitis, Streptococcus oralis, Streptococcus cristatus and

Abbreviations: FTF, fructosyltransferase; GTF, glucosyltransferase; MSA, mitis salivarius agar.

The GenBank accession number for the $16 \mathrm{~S}$ rDNA sequence of strain A63 ${ }^{\top}$ is AF124350.
Streptococcus parasanguinis (Hamada \& Slade, 1980; Marsh \& Martin, 1992; Willcox, 1996). Streptococcus salivarius and Streptococcus vestibularis are isolated from the mucous membranes of the oral cavity (Marsh $\&$ Martin, 1992). The mutans streptococci are usually isolated from dental plaque (Hamada \& Slade, 1980; Marsh \& Martin, 1992). There are seven different species of mutans streptococci, including Streptococcus ratti and Streptococcus ferus, which have been isolated from the oral cavity of rats. Most previous studies (Hamada \& Slade, 1980; Larrimore et al., 1983; Loesche, 1986; Rolla et al., 1983; Schilling \& Bowen, 1992) have demonstrated that dietary sucrose facilitates the colonization of the mutans streptococci on the teeth of humans, monkeys and rodents, as the mutans streptococci synthesize extracellular polysaccharides from sucrose. During an investigation of the effect of high-sucrose diets on the oral bacteria of Sprague-Dawley rats, a new type of $\alpha$-haemolytic Streptococcus was occasionally isolated. This organism occurred in about $50 \%$ of the experimental rat mouths and increased as a percentage of the total streptococci in the mouths of rats fed with a high-sucrose diet (Zhu et al., 1997). In the current study, the physical, biochemical and serological characteristics of the new isolates were examined and compared with other oral streptococci. DNA-DNA hybridization was performed with oral streptococci to determine their 
relatedness. The $16 \mathrm{~S}$ rDNA sequence of the type strain was also analysed.

\section{METHODS}

Bacterial strains. The new strains A63 ${ }^{\mathrm{T}}$, B64, A69 and B610 were isolated from the surfaces of the lower molars of two Sprague-Dawley rats, before and after feeding with highsucrose diets, by using selective mitis salivarius agar (MSA) plates (Difco). The reference strains used in the study for comparative purposes are listed in Table 1. Stock cultures were maintained at $-70{ }^{\circ} \mathrm{C}$ in brain/heart infusion broth (Oxoid) containing 0.3\% (w/v) yeast extract (BHIY; Difco) supplemented with $30 \%$ glycerol.

Physiological and biochemical tests. The isolates were examined for their morphology, Gram reaction, catalase formation and ability to grow aerobically as well as anaerobically. For examination of haemolysis, strains were grown on $5 \%$ (v/v) Columbia sheep-blood-agar plates (Difco) under anaerobic conditions $\left(95 \% \mathrm{~N}_{2}, 5 \% \mathrm{CO}_{2}\right)$ at $37^{\circ} \mathrm{C}$ for $18 \mathrm{~h}$. Bacterial tolerance to bile salts was assessed by determining their ability to grow on Columbia bloodagar base supplemented with $10 \%$ and $40 \%$ Bacto Oxgall (Difco). Salt tolerance of the bacteria was tested in BHIY broth containing $6.5 \%(\mathrm{w} / \mathrm{v}) \mathrm{NaCl}$. The capacity for bacterial growth at 45 and $50{ }^{\circ} \mathrm{C}$ was examined in BHIY broth. To determine the growth of the isolates at $\mathrm{pH} 9 \cdot 6$, the strains were incubated in BHIY broth adjusted to this $\mathrm{pH}$ by the addition of $1 \mathrm{M} \mathrm{NaOH}$. The final $\mathrm{pH}$ of bacterial cultures was determined after inoculation and incubation $\left(37^{\circ} \mathrm{C}\right)$ of the bacteria in BHIY broth containing an excess of glucose $(5 \%)$ for $3 \mathrm{~d}$.
The ability of strains to hydrolyse starch was tested by using the method of Paik (1980). Briefly, the organisms were grown on BHIY agar plates supplemented with $2 \%$ soluble potato starch (BDH) for $48 \mathrm{~h}$ at $37^{\circ} \mathrm{C}$. After flooding the surface of the plate with $1 \%(\mathrm{w} / \mathrm{v})$ iodine, a colourless zone indicated hydrolysis and a dark blue to purple colour indicated that the starch had not been hydrolysed. API 20 Strep, Rapid ID32 Strep and API 50 CHS test kits were used according to the manufacturer's instructions (bioMérieux Vitek) for the further characterization of the organisms.

Serological reactions. Lancefield group typing was performed with a Streptococcal grouping kit (Oxoid). After growing on Columbia blood-agar plates at $37^{\circ} \mathrm{C}$ for $18 \mathrm{~h}$, a loopful of pure culture was emulsified in $0.4 \mathrm{ml}$ Oxoid extraction enzyme and incubated in a water bath $\left(37^{\circ} \mathrm{C}\right)$ for $10 \mathrm{~min}$. The extracts were then used for the Lancefield grouping reaction following the manufacturer's instruction.

Production of glucosyltransferase (GTF) and fructosyltransferase (FTF). For the examination of the production of GTF and FTF, Streptococcus sobrinus 6715 was used as the positive control, as this strain is well known to produce GTF and FTF (Willcox et al., 1993). The bacterial strains were grown in BHIY for $18 \mathrm{~h}$ and harvested by centrifugation $\left(6000 \mathrm{~g}, 4^{\circ} \mathrm{C}, 15 \mathrm{~min}\right)$. Extracellular and cell-bound GTF and FTF activities were assayed with radioactive substrates as described previously (Jacques, 1983; Jacques \& Wittenberger, 1981).

DNA isolation. Strains were cultured in $10 \mathrm{ml}$ BHIY at $37^{\circ} \mathrm{C}$ for $18 \mathrm{~h}$. The cells were harvested and washed once in TE buffer (50 mM Tris/HCl, pH 7·5; 20 mM EDTA). Chromo-

Table 1. DNA similarity between strain $A 63^{\top}$ and other test strains

\begin{tabular}{|c|c|c|}
\hline Strain & Source & $\begin{array}{c}\text { DNA } \\
\text { similarity } \\
(\%)\end{array}$ \\
\hline $\mathrm{A} 63^{\mathrm{T}}$ & Rat, oral cavity & 100 \\
\hline B64 & Rat, oral cavity & 100 \\
\hline A69 & Rat, oral cavity & $98 \cdot 8$ \\
\hline B610 & Rat, oral cavity & $99 \cdot 4$ \\
\hline S. anginosus NCTC $10713^{\mathrm{T}}$ & Human, throat & $14 \cdot 8$ \\
\hline S. bovis ATCC 33317 & Cow, dung & $27 \cdot 3$ \\
\hline S. bovis $2 \mathrm{M} 2$ & Human, oral cavity & $25 \cdot 8$ \\
\hline S. constellatus NCTC $11325^{\mathrm{T}}$ & Human, purulent pleurisy & $6 \cdot 4$ \\
\hline S. criceti $\mathrm{E} 49$ & Hamster, oral cavity & $6 \cdot 6$ \\
\hline S. equinus ATCC $9812^{\mathrm{T}}$ & Human, faeces & $18 \cdot 7$ \\
\hline S. gordonii ATCC $10558^{\mathrm{T}}$ & Human, SBE & $13 \cdot 2$ \\
\hline S. intermedius NCTC $11324^{\mathrm{T}}$ & Human & $21 \cdot 5$ \\
\hline S. mitis NCTC $12261^{\mathrm{NT}}$ & Human, SBE & $18 \cdot 7$ \\
\hline S. oralis NCTC $11427^{\mathrm{T}}$ & Human, oral cavity & $10 \cdot 0$ \\
\hline S. parasanguinis ATCC $15912^{\mathrm{T}}$ & Human, throat & $18 \cdot 0$ \\
\hline S. pyogenes NCTC 8198 & Human, scarlet fever & $27 \cdot 9$ \\
\hline S. ratti FA1 & Rat, oral cavity & $24 \cdot 1$ \\
\hline S. salivarius ATCC 25975 & Human, oral cavity & $28 \cdot 6$ \\
\hline S. sanguinis NCTC $7863^{\mathrm{T}}$ & Human, SBE & $16 \cdot 4$ \\
\hline S. sobrinus 6715 & Human, oral cavity & ND \\
\hline S. suis ATCC 43765 & Pig, throat & $20 \cdot 2$ \\
\hline
\end{tabular}

SBE, Subacute bacterial endocarditis; ND, not determined. 
somal DNA was then isolated from all the test strains as described previously (Willcox, 1996). Briefly, the cells were resuspended and incubated in $350 \mu \mathrm{TE}$ buffer containing mutanolysin (125 units) at $60{ }^{\circ} \mathrm{C}$ for approximately $2 \mathrm{~h}$. After lysing cells by the addition of $20 \mu \mathrm{l} 20 \%$ (w/v) SDS, $5 \mu \mathrm{l} 20 \mathrm{mg}$ proteinase $\mathrm{K} \mathrm{ml}^{-1}$ was added and incubated at $37^{\circ} \mathrm{C}$ for $1 \mathrm{~h}$. Protein was then precipitated by the addition of $200 \mu$ saturated $\mathrm{NaCl}$ solution and removed by centrifugation. The residual RNA was removed by incubating with RNase at $37^{\circ} \mathrm{C}$ for $1 \mathrm{~h}$. The DNA was further purified by adding an equal volume of equilibrated phenol, next with an equal volume of phenol/chloroform $(1: 1)$ and finally with an equal volume of chloroform. The DNA was precipitated by addition of $10 \mu 1.0 \mathrm{M}$ sodium acetate followed by 0.6 vols propan-2-ol.

Determination of DNA $\mathbf{G}+\mathbf{C}$ content. Base compositions $(\mathrm{G}+\mathrm{C}$ contents) of the new isolates were determined by the thermal melting method $\left(T_{\mathrm{m}}\right)$ described by Johnson (1981). The $A_{260}$ of the DNA sample was recorded continually while the sample was heated $1.0{ }^{\circ} \mathrm{C} \min ^{-1}$ from 50 to $95^{\circ} \mathrm{C}$. A reference DNA sample was prepared from Escherichia coli O157.

DNA-DNA hybridization. DNA-DNA hybridization was based on the method described by Kusuda et al. (1991) and Willcox (1996) using the enhanced chemiluminescence (ECL) gene detection system (Amersham). Briefly, DNAs of all test strains were dissolved in water, boiled for $5 \mathrm{~min}$ and then immediately chilled. The single-strained DNA was spotted in equal amounts $(10 \mu \mathrm{g}$ for each strain) onto nitrocellulose membranes. After pre-treating in hybridization buffer at $42^{\circ} \mathrm{C}$ for $1 \mathrm{~h}$, the membrane was reacted with a peroxidase-labelled DNA probe of the new isolate $\mathrm{A} 63^{\mathrm{T}}$ overnight at $42^{\circ} \mathrm{C}$. The membrane was transferred to detection reagents that included hydrogen peroxide, luminol and enhancer to produce chemiluminescence and then exposed to hyperfilm-ECL autoradiography film (Amersham). The hybridization was carried out under 'relaxed' conditions in $4.38 \mathrm{~g}$ sodium chloride $1^{-1}, 2.2 \mathrm{~g}$ sodium citrate $1^{-1}$ buffer, $\mathrm{pH} 7 \cdot 0(0 \cdot 5 \times \mathrm{SSC})$. The percentage similarity between the labelled DNA and the test-strain DNAs was determined by measuring the density of the dark spots formed on the developed film with a laser densitometer (LKB 2222-020 UltroScan XL).

16S rDNA amplification. The oligonucleotide primers used in this study were synthesized by Auspep (Victoria, Australia). Sequences of the primers corresponded to those within the 16S rDNA gene of $S$. sanguinis (Whiley et al., 1990a). The 5' primer 5'-CTGGCTCAGGACGAACG-3' corresponded to nucleotides $18-34$ of the $16 \mathrm{~S}$ rDNA. The $3^{\prime}$ primer 5'GCCCGGGAACGT ATTCAC-3' corresponded to nucleotides 1375-1392 (Whiley et al., 1990a). PCR was performed in a $100 \mu \mathrm{l}$ reaction containing template DNA (approx. $50 \mathrm{ng}), 2 \mu \mathrm{d}$ dNTP mix $(10 \mathrm{mM}$ each $), 10 \mu 110 \times$ reaction buffer [Tris/ $\mathrm{HCl}, \mathrm{KCl},\left(\mathrm{NH}_{4}\right)_{2} \mathrm{SO}_{4}, 3 \mathrm{mM} \mathrm{MgCl}, \mathrm{pH} 8 \cdot 7$ ], $50 \mathrm{pmol}$ of each primer and $2 \cdot 5$ units Taq DNA polymerase (Qiagen). The samples were first denatured for $3 \mathrm{~min}$ at $94^{\circ} \mathrm{C}$ and then subjected to 35 cycles of amplification in an FTS-320 thermal cycler (Corbett Research). Parameters for the amplification cycles were: denaturation for $1 \mathrm{~min}$ at $94{ }^{\circ} \mathrm{C}$, annealing of primers for $2 \mathrm{~min}$ at $53{ }^{\circ} \mathrm{C}$ and primer extension for $1.5 \mathrm{~min}$ at $72^{\circ} \mathrm{C}$. After the last cycle, the PCR tubes were incubated for $7 \mathrm{~min}$ at $72{ }^{\circ} \mathrm{C}$. On completion, the sample was extracted with 0.6 vols propan-2-ol, precipitated with 2.5 vols ethanol and resuspended in $20 \mu$ distilled water for direct sequencing.
16S rDNA sequencing and sequence analysis. The amplified $16 \mathrm{~S}$ rDNA products were sequenced in the Prince Alfred Macromolecular Analysis Centre, University of Sydney, by using standard dye-terminator chemistry. The sequences were then aligned and the homology values were determined by using the WeBANGIS program (Australian National Genomic Information Services). The unrooted phylogenetic tree was generated by using the neighbour-joining method (ENEIGHBOUR algorithm) in the WEBANGIS software.

\section{RESULTS}

\section{General characteristics}

After incubating for $3 \mathrm{~d}$ on MSA plates, colonies of the new isolate were approximately $0.5-1.0 \mathrm{~mm}$ in diameter, rough or heaped. On blood-agar plates, strains produced small, white, rough colonies with $\alpha$-haemolysis. After three or four subcultures, the colonies changed to a smooth colony type. Adherent growth to the vessel wall in broth culture was observed. The cells were Gram-positive cocci in pairs or in short to moderate chains (three to six cells per chain). The isolates were catalase-negative and grew well under both anaerobic and aerobic conditions. Growth occurred on 10 and $40 \%$ bile agar plates and also in broth of $\mathrm{pH} 9 \cdot 6$ and at 37 and $45^{\circ} \mathrm{C}$ but not at $50{ }^{\circ} \mathrm{C}$. There was no growth in broth with $6.5 \% \mathrm{NaCl}$. The terminal $\mathrm{pH}$ in glucose-containing broth media was $4 \cdot 3-4 \cdot 4$.

\section{Biochemical characteristics}

Table 2 shows the biochemical characteristics of the new species, reference strains Streptococcus suis ATCC 43765, bovine Streptococcus bovis ATCC 33317, human S. bovis 2M2, S. ratti FA1 and Streptococcus pyogenes NCTC 8198. For all four strains of the new species (Table 2), aesculin and starch were hydrolysed but arginine was not utilized. Acetoin, GTF and FTF were not produced. The isolates were negative for pyrrolidonylaryl amidase, $\alpha$-galactosidase, $\beta$ glucuronidase, $\beta$-galactosidase and alkaline phosphatase. Acid was produced from lactose, trehalose, inulin, raffinose, glycogen, amygdalin, galactose, glucose, fructose, mannose, glucosamine, arbutin, salicin, cellobiose, maltose, melibiose and sucrose. Acid was not produced from ribose, L-arabinose, mannitol, sorbitol or melezitose. The strains gave a positive reaction for the Lancefield group A antigen and negative reactions for the other grouping antigens.

\section{API Rapid Strep identification}

The biochemical profile of the isolates in API 20 Strep (4040473) was interpreted by the API LAB computer system as an unacceptable one. The presumptive identification included $S$. bovis II (34.2\% identity), $S$. bovis I (34.0\%), Streptococcus pneumoniae (11.9\%), S. sanguinis $(9.9 \%)$ and $S$. suis II $(7 \cdot 5 \%)$. The identification obtained by using the Rapid ID32 Strep kit 
Table 2. Characteristics that differentiate $S$. orisratti sp. nov. from related streptococci

All four strains of $S$. orisratti showed the same characteristics by the tests shown. ND, Not determined.

\begin{tabular}{|c|c|c|c|c|c|c|}
\hline Characteristic & S. orisratti & $\begin{array}{c}\text { S. suis ATCC } \\
43765\end{array}$ & $\begin{array}{c}\text { Bovine } S \text {. bovis } \\
\text { ATCC } 33317\end{array}$ & $\begin{array}{l}\text { Human } S . \\
\text { bovis } 2 \mathrm{M} 2\end{array}$ & $\begin{array}{l}\text { S. ratti } \\
\text { FA1 }\end{array}$ & $\begin{array}{l}\text { S. pyogenes } \\
\text { NCTC } 8198\end{array}$ \\
\hline \multicolumn{7}{|l|}{ Hydrolysis of: } \\
\hline Arginine* & - & + & - & - & + & + \\
\hline Aesculin* & + & + & + & + & + & - \\
\hline Hippurate* & - & - & - & - & - & - \\
\hline Starch & + & + & + & + & + & + \\
\hline \multicolumn{7}{|l|}{ Production of: } \\
\hline Acetoin* & - & - & + & + & + & - \\
\hline Glucan & - & - & - & + & + & - \\
\hline Fructan & - & - & - & + & + & - \\
\hline \multicolumn{7}{|l|}{ Activity of:* } \\
\hline Pyrrolidonylarylamidase & - & - & - & - & - & + \\
\hline$\alpha$-Galactosidase & - & + & + & - & + & - \\
\hline$\beta$-Glucuronidase & - & + & - & - & - & - \\
\hline$\beta$-Galactosidase & - & + & - & - & - & - \\
\hline Alkaline phosphatase & - & - & - & - & - & + \\
\hline Leucine arylamidase & + & + & + & + & + & + \\
\hline \multicolumn{7}{|l|}{ Growth in/at: } \\
\hline $6.5 \% \mathrm{NaCl}$ & - & - & - & - & - & ND \\
\hline $\mathrm{pH} 9 \cdot 6$ & + & ND & - & - & ND & ND \\
\hline $45^{\circ} \mathrm{C}$ & + & + & + & + & - & ND \\
\hline $10 \%$ Bile & + & + & + & + & + & ND \\
\hline $40 \%$ Bile & + & + & + & + & - & ND \\
\hline \multicolumn{7}{|l|}{ Fermentation of:* } \\
\hline Ribose & - & - & - & - & - & - \\
\hline L-Arabinose & - & - & + & - & - & - \\
\hline Mannitol & - & - & - & + & + & - \\
\hline Sorbitol & - & - & - & - & + & - \\
\hline Lactose & + & + & + & + & + & + \\
\hline Trehalose & + & + & - & + & + & + \\
\hline Inulin & + & + & + & + & - & - \\
\hline Raffinose & + & + & + & + & + & - \\
\hline Glycogen & + & + & + & + & - & + \\
\hline Amygdalin & + & + & + & + & - & + \\
\hline Lancefield antigen & A & $\mathrm{D}$ & $\mathrm{D}$ & - & - & A \\
\hline
\end{tabular}

* Data obtained from commercially available kits (API 20 Strep, Rapid ID32 Strep and API 50 CHS).

(profile 20072061111) was S. bovis II $(61 \cdot 1 \%)$, S. bovis I $(23.0 \%)$ and $S$. suis II $(15.7 \%)$. When using the API $50 \mathrm{CHS}$ system, the isolate was identified as $S$. suis II $(98.7 \%)$.

\section{DNA studies}

The $\mathrm{C}+\mathrm{G}$ content of DNA of the isolates was $39 \cdot 6-43 \cdot 5 \mathrm{~mol} \%$. Labelled DNA from the new isolate A63 ${ }^{\mathrm{T}}$ was used as the probe for DNA-DNA hybridization. The results of DNA hybridization (Table 1) showed high similarity values $(98 \cdot 8-100 \%)$ within the strains of the new species. However, DNA from various other oral streptococci showed sufficiently low DNA similarity values to the labelled
DNA (Table 1; DNA similarity ranging from 6.4 to $28.6 \%$ ) to warrant distinguishing the new species from other species of Streptococcus. DNA from the Lancefield group A Streptococcus species $S$. pyogenes NCTC 8198 had only $27.9 \%$ relatedness. DNA from the phenotypically similar species $S$. suis ATCC 43765 , $S$. bovis ATCC 33317 and human $S$. bovis $2 \mathrm{M} 2$ had $20 \cdot 2,27 \cdot 3$ and $25 \cdot 8 \%$ similarity, respectively.

The $16 \mathrm{~S}$ rDNA sequence of strain $\mathrm{A} 63^{\mathrm{T}}$ was determined for 1337 bases. The unrooted phylogenetic tree (Fig. 1) demonstrated that the new strain was located in the cluster of the mutans streptococci group. The strain was clearly a phylogenetically distinct taxon on the basis of the sequence data, although there was a loose phenotypic affinity between the new species and 


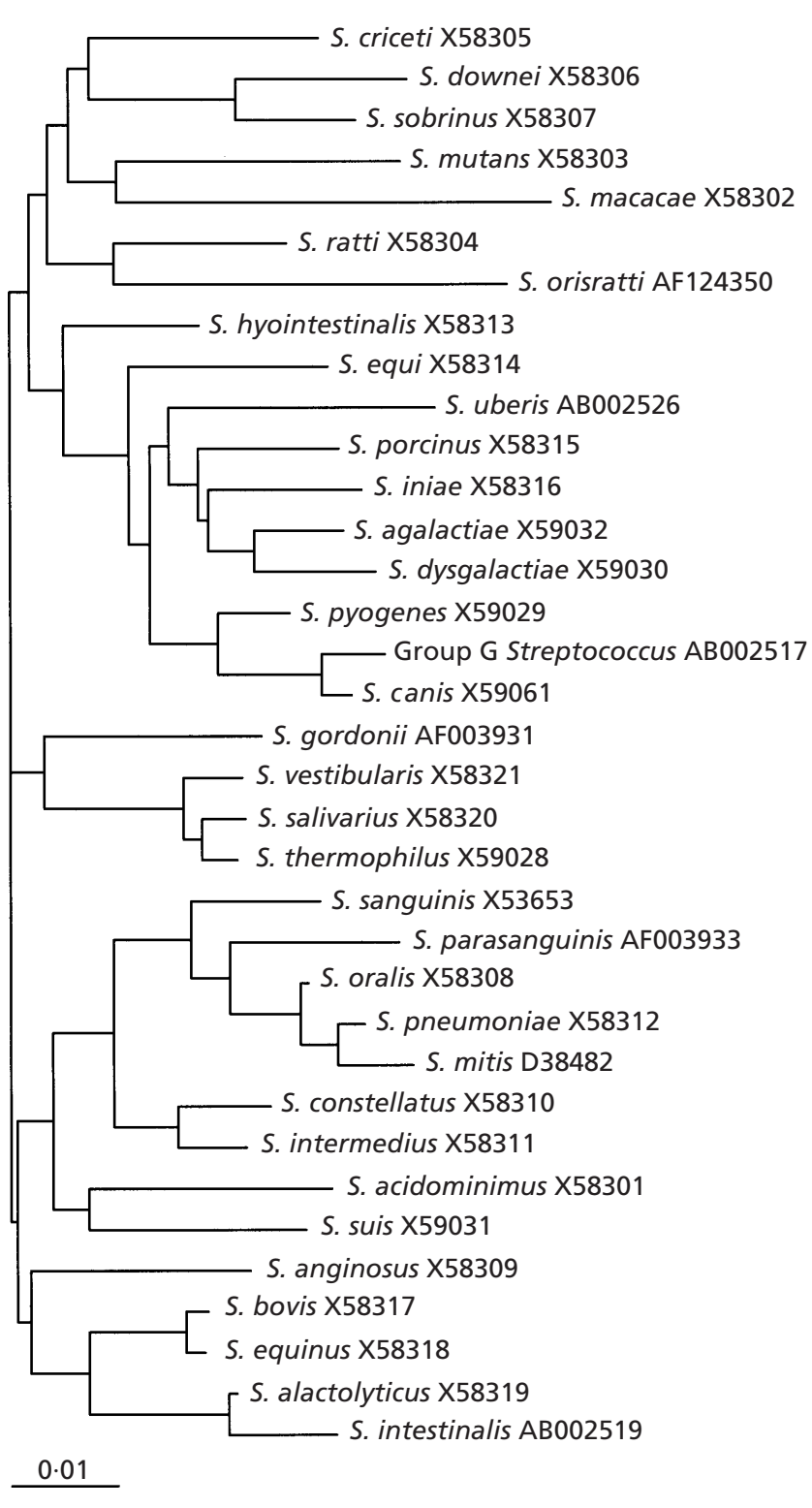

Fig. 1. Unrooted tree showing the phylogenetic relationships of S. orisratti to some other streptococci. Accession numbers of the sequences are shown.

S. ratti. The overall sequence homology to the nearest relative strain $S$. ratti for a continuous stretch of 1265 bases was $94.1 \%$, corresponding to 75 nucleotide differences. This number of nucleotide differences is consistent with discrete species.

\section{DISCUSSION}

According to the biochemical characteristics, the most closely related Streptococcus species to the new isolates was $S$. suis (Table 2), as members of both species were Voges-Proskauer-negative, aesculin-positive, trehalose-positive, failed to grow in the presence of $6.5 \% \mathrm{NaCl}$ and did not show $\beta$-haemolysis on sheep- blood agar (Tarradas et al., 1994). S. suis is an important emerging cause of meningitis, pneumonia, septicaemia and arthritis in young piglets (Touil et al., 1988; Windsor, 1977) and it has also been implicated in different types of infections in other animals such as ruminants and horses (Devriese et al., 1990; Higgins et al., 1990). In addition, meningitis caused by S. suis in humans has been reported (Arends \& Zanen, 1988; Chau et al., 1983). Both the tonsils and the nose have been shown to be carrier sites of $S$. suis in pigs. In our study, new isolates were distinguished biochemically and serologically from $S$. suis (Table 2) by the absence of arginine hydrolysis, the presence of Lancefield group A antigen, low DNA-hybridization similarity values (Table 1) and the unique 16S rDNA sequence.

Another bacterium, $S$. bovis, appeared to resemble the new species. S. bovis also hydrolysed aesculin, produced acid from lactose, sucrose, raffinose, amygdalin and glycogen and did not grow in $6.5 \% \mathrm{NaCl}$. S. bovis is commonly isolated from the alimentary tract of cows, sheep and other ruminants and has been shown to cause endocarditis in elderly people (Hoppes \& Lerner, 1974; Moellering et al., 1974). In taxonomic studies, it has been shown that many bovine strains, including the type strain, are not typical of $S$. bovis strains derived from humans (Knight \& Shlaes, 1985). Two biotypes of $S$. bovis derived from humans have been recognized. Biotype I ferments mannitol, hydrolyses starch and produces glucan from sucrose, whereas biotype II (or S. bovis variant) gives negative results in all these tests (Facklam, 1972; Knight \& Shlaes, 1985). However, the bovine type strain hydrolysed starch but failed to form acid from mannitol. The new isolates were more similar to the bovine type strain but differed in having no ability to produce acetoin and in the presence of the Lancefield group A antigen. Additionally, there was no significant genetic similarity between the new species and $S$. bovis.

Initially, due to the appearance of the rough and heaped colonies on MSA plates, the new isolates were characterized as members of the mutans streptococci group. However, more detailed biochemical experiments indicated that they differed from $S$. ratti and $S$. ferus, as they failed to ferment mannitol or sorbitol and had no GTF or FTF activities (Table 2). Moreover, the new isolates reacted with Lancefield group A antisera and had distinct 16S rDNA sequences (Fig. 1).

The new isolates possessed the Lancefield group A antigen. This antigen also occurs in some members of the 'Streptococcus milleri' group (with others possessing the $\mathrm{C}, \mathrm{F}$ or $\mathrm{G}$ antigen; Gossling, 1988; Whiley et al., 1990b). There are three related species in the 'S. milleri' group, Streptococcus anginosus, Streptococcus intermedius and Streptococcus constellatus (Whiley \& Beighton, 1991; Whiley \& Hardie, 1989). Members of these species have been isolated from the human oral cavity, where they have been implicated in dental caries (Drucker \& Melville, 1971) and dental 
abscess (Williams et al., 1983). However, the new isolates were differentiated from the ' $S$. milleri' group by fermentation of inulin and raffinose, absence of arginine hydrolysis and having significantly low DNA similarity values towards them (Table 1).

It has been demonstrated that the Lancefield A antigenic determinant consists of a branched rhamnose chain with a terminal $\mathrm{N}$-acetylglucosamine (Hardie, 1986); therefore the current results imply that similar residues may be integral parts of the cell wall of the new isolates. Group A streptococci colonize the nasopharyngeal mucosa of humans, leading either to an inflammatory response followed by clinical illness or to an asymptomatic carrier state. Group A $S$. pyogenes strains are almost always $\beta$-haemolytic. The new species was $\alpha$-haemolytic and was biochemically and genetically distinct from the classic group A streptococci.

On the basis of their physical, biochemical, serological and genetic characteristics, we concluded that the isolates represented a new species of oral Streptococcus, for which we propose the name Streptococcus orisratti sp. nov. This new species was isolated from the mouths of Sprague-Dawley rats. Care should be taken when Sprague-Dawley rats are used as a model to study the effect of oral bacteria on dental caries, as the new species is morphologically similar to members of the mutans streptococci on MSA plates. Further studies should be undertaken to evaluate the cariogenic potential of this isolate.

\section{Description of Streptococcus orisratti sp. nov.}

Streptococcus orisratti (o.ris.rat'ti. L. gen. n. oris of the mouth; L. gen. masc. n. ratti of the rat; M.L. gen. n. orisratti of the mouth of the rat).

Cells are facultatively anaerobic, non-motile, catalasenegative, Gram-positive cocci that occur in pairs or short chains. Colonies are white, circular or irregular, $0.5-1.0 \mathrm{~mm}$ in diameter and $\alpha$-haemolytic on sheepblood agar. Growth occurs at $45{ }^{\circ} \mathrm{C}$, in $40 \%$ bile and at $\mathrm{pH} 9 \cdot 6$, but not in the presence of $6.5 \% \mathrm{NaCl}$ or at $50{ }^{\circ} \mathrm{C}$. Ferments galactose, glucose, fructose, mannose, glucosamine, amygdalin, arbutin, salicin, cellobiose, maltose, lactose, melibiose, sucrose, trehalose, inulin, raffinose, starch and glycogen, but not arabinose, mannitol, sorbitol or melezitose. The final $\mathrm{pH}$ in glucose-containing culture is $4 \cdot 3-4 \cdot 4$. Aesculin and starch are hydrolysed but arginine is not. GTF and FTF are not produced. $S$. orisratti belongs to Lancefield group A. The $\mathrm{G}+\mathrm{C}$ content of DNA is $39 \cdot 6-43.5 \mathrm{~mol} \%$. Source: the tooth surface of laboratory rats. The type strain is $\mathrm{A}^{2} 3^{\mathrm{T}}$ (=ATCC $\left.700640^{\mathrm{T}}\right)$.

\section{ACKNOWLEDGEMENTS}

We wish to thank Dr Wendy Relf for help and advice on primer design and PCR and Simon L. Cook for assistance on using the ANGIS programs to analyse gene sequences. This study was supported financially by the Equal Merit Scholarship Scheme from Australia International Development Assistance Bureau.

\section{REFERENCES}

Arends, J. P. \& Zanen, H. C. (1988). Meningitis caused by Streptococcus suis in humans. Rev Infect Dis 10, 131-137.

Chau, P. Y., Huang, C. Y. \& Kay, R. (1983). Streptococcus suis meningitis. An important underdiagnosed disease in Hong Kong. Med J Aust 1, 414-417.

Colman, G. (1976). The viridans streptococci. In Selected Topics in Clinical Bacteriology, pp. 179-198. Edited by J. de Louvois. London: Bailliere Tindal.

Devriese, L. A., Sustronck, B., Maenhout, T. \& Haesebrouck, F. (1990). Streptococcus suis meningitis in a horse. Vet Rec 127, 68. Drucker, D. B. \& Melville, T. H. (1971). The classification of some oral streptococci of human or rat origin. Arch Oral Biol 16, 845-853.

Facklam, R. R. (1972). Recognition of group D streptococcal species of human origin by biochemical and physiological tests. Appl Microbiol 23, 1131-1139.

Facklam, R. R. (1977). Physiological differentiation of viridans streptococci. J Clin Microbiol 5, 184-201.

Gilmour, M. N., Whittam, T. S., Kilian, M. \& Selander, R. K. (1987). Genetic relationships among the oral streptococci. J Bacteriol 169, 5247-5257.

Gossling, J. (1988). Occurrence and pathogenicity of the Streptococcus milleri group. Rev Infect Dis 10, 257-285.

Hamada, S. \& Slade, H. D. (1980). Biology, immunology, and cariogenicity of Streptococcus mutans. Microbiol Rev 44, 331-384.

Hardie, J. M. (1986). Oral streptococci. In Bergey's Manual of Systematic Bacteriology, vol. 2, pp. 1054-1063. Edited by P. H. A. Sneath, N. S. Mair, M. E. Sharpe \& J. G. Holt. Baltimore: Williams \& Wilkins.

Hardie, J. M. \& Bowden, G. H. (1976). Physiological classification of oral viridans streptococci. J Dent Res 55, A166-A176.

Higgins, R., Gottschalk, M., Fecteau, G., Sauvageau, R., Deguise, S. \& Tremblay, D. D. (1990). Isolation of Streptococcus suis from cattle. Can Vet J 31, 529.

Hoppes, W. L. \& Lerner, P. I. (1974). Nonenterococcal group-D streptococcal endocarditis caused by Streptococcus bovis. Ann Intern Med 81, 588-593.

Jacques, N. A. (1983). Membrane perturbation by cerulenin modulates glucosyltransferase secretion and acetate uptake by Streptococcus salivarius. J Gen Microbiol 129, 3293-3302.

Jacques, N. A. \& Wittenberger, C. L. (1981). Inactivation of cellassociated fructosyltransferase in Streptococcus salivarius. J Bacteriol 148, 912-918.

Johnson, J. L. (1981). Genetic characterization. In Manual of Methods for General Bacteriology, pp. 450-472. Edited by P. Gerhardt, K. G. E. Murray, R. N. Costilow, E. W. Nester, W. A. Wood, N. R. Krieg \& G. B. Phillips. Washington, DC: American Society for Microbiology.

Knight, R. G. \& Shlaes, D. M. (1985). Physiological characteristics and deoxyribonucleic acid relatedness of human isolates of Streptococcus bovis and Streptococcus bovis (var.). Int J Syst Bacteriol 35, 357-361.

Kusuda, R., Kawai, K., Salati, F., Banner, C. R. \& Fryer, J. L. (1991). 
Enterococcus seriolicida sp. nov., a fish pathogen. Int J Syst Bacterial 41, 406-409.

Larrimore, S. H., Murchison, H., Shiota, T., Michalek, S. M. \& Curtiss, R., III (1983). In vitro and in vivo complementation of Streptococcus mutans mutants defective in adherence. Infect Immun 42, 558-566.

Loesche, W. J. (1986). Role of Streptococcus mutans in human dental decay. Microbiol Rev 50, 353-380.

Marsh, P. D. \& Martin, M. (1992). Oral Microbiology, 3rd edn. London: Chapman \& Hall.

Moellering, R. C., Jr, Watson, B. K. \& Kunz, L. J. (1974). Endocarditis due to group D streptococci. Comparison of disease caused by streptococcus bovis with that produced by the enterococci. Am J Med 57, 239-250.

Paik, G. (1980). Reagents, stain, and miscellaneous test procedures. In Manual of Clinical Microbiology, pp. 1000-1024. Edited by E. H. Lennette, A. Balows, W. J. Hausler, Jr \& J. P. Truant. Washington, DC: American Society for Microbiology.

Parker, M. T. \& Ball, L. C. (1976). Streptococci and aerococci associated with systemic infection in man. J Med Microbiol $\mathbf{9}$, 275-302.

Rolla, G., Ciardi, J. E., Eggen, K. E., Bowen, W. H. \& Afseth, J. (1983). Free glucosyl- and fructosyltransferase in human saliva and adsorption of these enzymes to teeth in vivo. Chem Senses (Spec. Suppl.), 21-29.

Schilling, K. M. \& Bowen, W. H. (1992). Glucans synthesized in situ in experimental salivary pellicle function as specific binding sites for Streptococcus mutans. Infect Immun 60, 284-295.

Tarradas, C., Arenas, A., Maldonado, A., Luque, I., Miranda, A. \& Perea, A. (1994). Identification of Streptococcus suis isolated from swine: proposal for biochemical parameters. J Clin Microbiol 32, 578-580.

Touil, F., Higgins, R. \& Nadeau, M. (1988). Isolation of
Streptococcus suis from diseased pigs in Canada. Vet Microbiol 17, 171-177.

Whiley, R. A. \& Beighton, D. (1991). Emended descriptions and recognition of Streptococcus constellatus, Streptococcus intermedius, and Streptococcus anginosus as distinct species. Int $J$ Syst Bacteriol 41, 1-5.

Whiley, R. A. \& Hardie, J. M. (1989). DNA-DNA hybridization studies and phenotypic characteristics of strains within the 'Streptococcus milleri group'. J Gen Microbiol 135, 2623-2633.

Whiley, R. A., Fraser, H. Y., Douglas, C. W. I., Hardie, J. M., Williams, A. M. \& Collins, M. D. (1990a). Streptococcus parasanguis sp. nov., an atypical viridans Streptococcus from human clinical specimens. FEMS Microbiol Lett 56, 115-121.

Whiley, R. A., Fraser, H. Y., Hardie, J. M. \& Beighton, D. (1990b). Phenotypic differentiation of Streptococcus intermedius, Streptococcus constellatus, and Streptococcus anginosus strains within the 'Streptococcus milleri group'. J Clin Microbiol 28, 1497-1501.

Willcox, M. D. P. (1996). Identification and classification of species within the Streptococcus sanguis group. Aust Dent J 41, 107-112.

Willcox, M. D. P., Fitzgerald, R. J., Adams, B. O., Patrikakis, M. \& Knox, K. W. (1993). Biochemical properties of Streptococcus sobrinus reisolates from the gastrointestinal tract of a gnotobiotic rat. J Gen Microbiol 139, 929-935.

Williams, B. L., McCann, G. F. \& Schoenknecht, F. D. (1983). Bacteriology of dental abscesses of endodontic origin. J Clin Microbiol 18, 770-774.

Windsor, R. S. (1977). Meningitis in pigs caused by Streptococcus suis type II. Vet Rec 101, 378-379.

Zhu, H., Willcox, M. D. P., Green, R. M. \& Knox, K. W. (1997). Effect of different diets on oral bacteria and caries activity in Sprague-Dawley rats. Microbios 91, 105-120. 